\title{
THE STYLE OF 'LOKAABHARAN' IN INDIAN PROVERBS
}

\author{
Biplab Chakraborty
}

\begin{abstract}
The changing pattern of Indian proverbs is very much reflected in various literary creations, especially in modern Indian poetry. Proverbs are used in poetry as a mode of creative process which entails change. Indeed, it is mostly expressed in a poetic style of narration which may be termed as the style of 'lokaabharan'. Various types of folk elements are used in the creative process and amongst such folk elements proverbs assume a very important position in the making of the style of 'lokaabharan'.

The central message of a proverb is often conveyed with a subtle touch of language use as a linguistic device. Patterns of changes in language use need to be examined with a view to measure the mode of expression of the proverb concerned. In order to understand the style of 'lokaabharan', we must examine how proverbs have been used as fixative factors. In this process, we need to compare and contrast the original proverbs used and their changing patterns available in the text of the poems concerned. Fixative factors are what may be called the core of folk elements used in a poem. This may be either a conscious creative effort or an unconscious artistic measure. It plays a vital role in conveying the central theme or message, whatever the case may be.
\end{abstract}

Key words: Indian proverbs, poetry, 'lokaabharan', Sanskrit literature, modern Indian literature

Indian proverbs have their own way of expressing messages, just as different nations have their proverbs characteristically permeated with national flavor. It means that proverbial wisdom is universal but its expression varies from language to language and, of course, from nation to nation. A good number of Indian proverbs, despite their language variations, stem from a lore called Indian tradition. There are many Indian proverbs that are found in the pages of Indian Classics, especially, Sanskrit literature. There are many Indian proverbs that originate in the Ramayana, the Mahabharata and so on; many of these proverbs convey messages in the fewest words and they are kept in Indian mind (i.e., folk mind) through the ages.

In modern Indian literature, proverbs have been used off and on as modes of typical folk expression or simply as modes of language use. In modern poetry, especially in modern Indian poetry, proverbs have been used as fixative factors. Here, a proverb is used not simply for the sake of sentence pattern. 
Instead, the body of a proverb is permeated deeply with the essence of the proverb leading to a different applied meaning or contextual meaning. The semantic change that occurs in this process involves a creative recreation of the proverb concerned. Many modern poets have resorted to this process of recreation leading to a distinct style of 'anonnoi lokaabharan', a style in which proverbs are indirectly related to the text. Here 'anonnoi' means something that is not directly related to the sentence structure or word use. So the proverb concerned is not visible in the sentence structure but it runs through every pore of the text. Folk-mind of a reader easily responds to it and enjoys it thereby appreciating the use of the proverb as a fixative factor.

Bakah paramah dharmikh - this is a typical Indian proverb that occurs in the Ramayana. Ramachandra, the hero of the great epic, described how pious a crane appears to be when it stands contemplating by the side of a pond. This proverb is sarcastically used to describe a hypocrite. Nagarjun, the leading modern Indian poet, uses this proverb as a fixative factor in one of his poems under the title Dhayanmagna Bakasiromoni, which is as follows:

\title{
Dhyanmagana \\ Bakasiromoni \\ Patli tango ke sahare \\ Jame hai jheel ke kinare \\ Jaane koun Istodev upke! (Nagarjun 1998: 57)
}

In this first stanza of the poem a complete picture of a crane standing on its thin legs and waiting patiently by the side of a pond is built up. It appears that it is deeply engrossed in contemplation but the poet sarcastically suggests that nobody knows the object of his contemplation. Here the poet does not use the proverb but builds up a picture based on the essential meaning of the proverb concerned.

Again, in the second stanza, the poem is composed at a different semantic level:

\author{
'Istodev' hai apke \\ Chapal-chatul laghu-laghu machchhalia \\ Chandi-si-chamkati machchalia \\ Fisneel, supachya \\ Sabere-sabere aap \\ Le chuke hai do char! \\ Aapna alpahaar! \\ Aa rahe hai jane kab se
}




\section{Chintanmadhya matsya-sisu}

Bhagawan nirakar!

The complete picture is changed with a sarcastic note on 'Istodev' (contemplated God) who is very clearly not only an object of contemplation but also an object of consumption, and so to say, an object of exploitation of a typical social hypocrite. So the crane is described as a person who is very much fixed in search of food. Again, as quickly moving fishes glitter as coins, a reader can realize what the real object of a hypocrite's contemplation is. The inner meaning of the proverb is far clearer in the final stanza:

Abhi to mahoday, aap

Date raho aayse prakar

Jheel ke kinare

Aapne 'ista' ke dhyan me!

Anokha hai aapka dhyan-jog!

Mahoday, mahamahim!

Addressing the 'Bakasiromoni', the poet says in his concluding remark, "you are still in the same place contemplating your 'Ishtha' (no more 'Deva' now) and so great you are!" Thus the poet uses two separate proverbs such as:

Bakah paramah dharmika! [What a pious crane!]

Bakah paramah darunah! [What a heartless crane!]

None of these proverbs have been used directly in the sentence structure or the phrase structure. Yet the whole poem is built up with these essential folk elements with an avowed intention to draw up a picture of somebody who is apparently a pious creature but is indeed a heartless social exploiter. It is evident that the poem is composed in an 'anonnoi lokaabharan' style leading to an indirect use of the proverbs.

Rabindranath Tagore, the foremost poet of modern India, composed a number of poems in 'lokaabharan' style using various types of folk elements as fixative factors. Some typical examples of poems composed in 'anonnoi lokaabharan' style (indirectly related to the text) may be cited from Tagore's Konika. Here is an example -

Bhakti aase rikto haste prosonna vadan

Oti bhakti bole, dekhi ki paile dhan

Bhakti koy, mone paai, naa paari dhekate,

Atibhakti koy, aami paai hate hate. (Ranchanavali 1980: 705) 
This is an example of 'lokaabharita kovita' (a poem totally skipped of folk elements). The only folk element in this poem is a Bengali proverb:

Otibhokti chorer lakshman. ['Two much courtesy, too much craft.']

So the poet says that 'bhakti' (devotion) comes empty-handed with marks of satisfaction on the face but 'otibhakti' (too much courtesy) enquires of crafty gain. While 'bhakti' cannot make any material gain except mental satisfaction, 'otibhakti' boasts of his material gain.

Thus, proverbs are used in an 'anonnoi lokaabharan' style wherein folk elements are indirectly used Utpakhi by Sudhindranath Dutta, Ghorsowar by Bishnu Dey, Agastha Yatra by Shankha Ghosh are but a few examples. Agasthya's Journey (Agasthya Yatra), a poem by Shankha Ghosh, is a typical example. This poem is composed in a form of dialogue between Agasthya, the Puranic Guru and his disciple, Vindhya, the mountain range in western India. The term 'Agasthya Yatra' is a proverb with the suggestion that a journey like that of Agasthya never ends, because a man like Agasthya never comes back to fulfill his promise. The Guru ordered his disciple not to raise his head upwards until the Guru's return and unfortunately the Guru never returned, thereby keeping his disciple in the same position, Shankha Ghosh, the poet, used this proverbial story as the fixative factor in the poem Agasthya Yatra. He wrote:

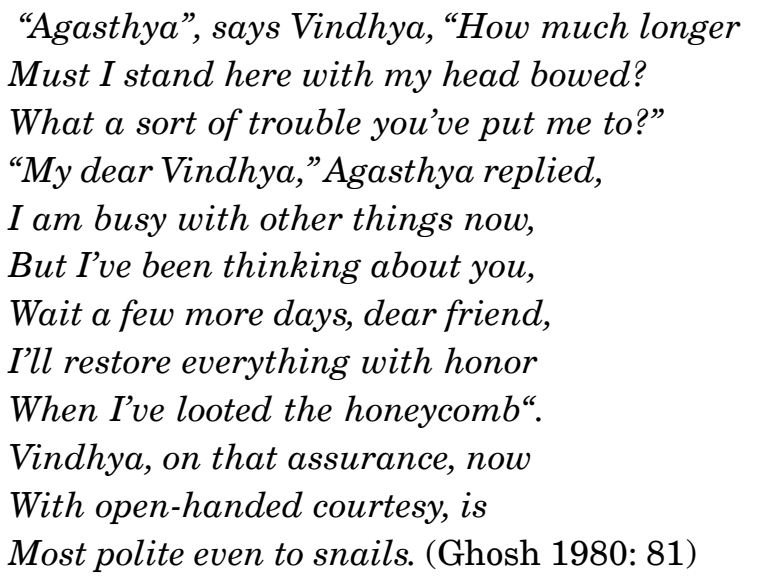

It must be kept in mind that this poem was composed as a protest against the promulgation of Emergency in India in 1975. This being a 'lokaabharita kovita' is totally soaked in a proverbial atmosphere based on a proverbial story. 
The other type of 'lokaabharan' apart from 'anonnoi' is 'annoi lokaabharan' (folk elements directly related to the text). There may be five types of 'annoi lokaabharan' depending upon the use of the folk element as a fixative factor either at sentence structure level, or at phrase structure level or at the conjoint level of two or more ideas. It may be indicative of the folk element essentially denoted by a compound verb and, again, it may be used as a complement to the whole idea at the end (for a detailed discussion of this typification see Chakraborty 2005). In 'annoi' style of 'lokaabharan' proverbs are frequently used as fixative factors. A composite transfer of name and sense occurs when a proverb is used in a sentence structure. 'Gharigali Ansu' is a proverb in Hindi which is an equivalent to 'crocodile tears' in English. A modern poet used this idiom employing its essential meaning in different sentence structures such as:

'Dost kise ho?'

'Khus hu- lahut khus; uska jababtha!

Kitna to lhala hai mera a as-paas, Janha log duki na hote hue bhi tumbhare liye

Ankho me ansu la sakte hai

Uchhal Sakte hai (Gaur 1975: 685-686).

In this poem Ramesh Gaur, the poet, uses the idiom referred to in the sentence

Jjanha log dukhi na hote hue bhi tumhare liye ankho men ansu laa sakkte hai.

And yet another sentence that follows is added to it. It is so done in order to strengthen the idea applied, the poet develops the idea of shedding tears without any touch of unhappiness felt for the person concerned. Here he used proverb as a fixative factor and conjoins them leading to the style of 'vakyannoi lokaabharan' ('lokaabharan' based on two conjoining sentences.

Some popular English proverbs are used by Indian poets in their poems. In such cases, poets compose their poems in the style of 'vakyannoi lokaabharan' ('lokaabharan' based on the style of conjoining sentence structure). Here a poet puts the central idea as one set against a proverbial saying. Here are two specific examples. In one of his poems, Umashankar Joshi, the foremost Gujarati poet, writes: 
Men die, die, die, day and night

But do not know how to die thoroughly.

Death, cowardly death, cannot conquer anyone.

It selects and gathers our near and dear ones

And that is its victory! (Ibid.)

It appears in the very first sentence that the poet wants to reiterate the proverbial saying, "Cowards die many times before their death". In the second sentence conjoined, the poet on the other hand, uses the adjective 'coward' for death. Thus the poet changes the essential meaning of the proverbial saying and applies yet another meaning that it is death and not a man who is coward.

The style of 'vakyannoi lokaabharan' has thus been successfully applied in order to convey the poet's message of man's unending march over cowardly death. There is yet another example that may be quoted from a poem composed by Sunil Ganguly:

All sorrows are not pure.

All dreams are not to be kept open to others

All roads do not lead to Rome

Love not for women alone. ${ }^{1}$

In a cluster of negative sentences, a proverbial sentence that all roads lead to Rome is set at naught with an avowed intention to convey a poetic message relating to personal sorrows or woes.

Indian proverbs with stories contained therein are often used in a poem in the style of 'lokaabharan' without changing the proverbial text available in oral literature. It means that text of a proverbial saying is not necessarily changed whenever it is used as a raw material in the creative process of the style of 'lokaabharan'. In this sense, 'lokaabharan' is essentially a style or a mode of narration pertaining to socio-cultural reality.

A very popular example of an Indian proverb with an inner story set within may be cited.

\section{Dasa chakre bhagaval bhut.}

The essence of the proverbial saying that in the opinion of the majority, a good man is turned into a devil as the majority rules the world. The story contained within the proverb is as follows: 
Bhagawan, a man of simplicity and truthfulness, was very dear to a king. A gang of courtiers grew jealous of him and one day they declared Bhagawan was the death. Now as the king was very anxious to meet Bhagawan, his friend courtiers took him to the site where Bhagawan was seen with a ghostly appearance at a long distance.

The text of this story is orally available and hence there may be variations of the contents of the text. Someone says that the king was really afraid of seeing his friend who turned into a ghost. Others say that the king realized the truth that in the opinion of the majority, Bhagawan turned into a devil.

Now this well-known folk tale containing the proverb is again used by Kazi Nazrul Islam, a famous Indian poet during to pre-independence period, in one of his poem named Pother Disha (In Search of a Way Out).

\section{Bhagawan aaj bhout holo je pare daso cakra fere Jaban aar kafer mile hay becharay firche pere (Nazrul Islam 1996: 332).}

Obviously, there is a new dimension added to the popular story as the poet intends to narrate the story in a new socio-political situation pervaded by communal holocaust. During pre-independence days, the poet observed that HinduMuslim communal strife caused a great threat to the national struggle for independence and the poet being unhappy about communal disharmony composed this poem, Pother Disha, wherein he used the proverb with an added dimension. Here Bhagawan is identified with the truth as he happens to be the target of 'jaban' (Muslim) and 'kafer' (Hindu) altogether. Usually, 'jaban' and 'kafer' are at daggers drawn with each other but here in this poem they are seen to be united at their chase after Bhagawan. Indeed, this is nothing but a socio-political narration in the style of 'bakyannoi lokaabharan'.

Apart from the poetic narration of a socio-political situation, there are some other types of narration that Indian poets often indulge in. They often use the Indian concept of purity that is very much expressed in proverbial sayings such as 'Tulsi pata' (holy basil) or 'dhoa-tulsi' (basil leaf in holy water) and 'gangajal' (sacred water of the Ganges). Some modern poets have these proverbial folk elements as fixative factors. Dharamvir Bharati, for instance, writes in his poem Swarga ke Mout:

Swarga se paataal tak jo ek dhara ban bahi

par na akhirk ek dinwah bhi rahi

mar goyi kovita wahi 
ek tulsi patra aur do bund ganga Jal bina

mar gaye kovita nahi tum ne sunaa? (Bharati 1999: 175)

The poet sarcastically observes that poetry died some day somewhere in the long-drawn flow from the heaven to the underworld without having a touch of the holy basil and a drop of sacred water. Here the folk elements used to denote a kind of folk belief at the phrase structure level as the style of 'padannoi lokaabharan'.

'Dhoa tulsi pata' being the same element has been used by Annada Shankar Roy, the poet, who wrote:

Hallo, dear man,

Can you tell me where must I get

Holy basil leaf washed in holy water?

I went to Rome to find it there

No, it's not there.

I came back from Tokyo

No, it's not there

Here in Kolkata I searched for it,

No, it's not here.

I intend to know the address

Where I must get it

Holy basil leaf washed in holy water. (Roy 1998: 323)

The search for a leaf of holy basil washed in holy water is impossibility. The proverb 'Dhoa tulsi pata' suggests that no human being is flawless and perfect. So the poet travels through the world in vain to find it out. Thus a beautiful poem has been composed using a proverb as its central theme in various sentence structures joined together. It is evident that the poem is deeply steeped in folk consciousness relating to eternal human folly.

Proverbs are used as basic elements in a poem depending on modes of poetic narration. The proverb poem, besides such others, composed by Annada Shankar Roy is but one of the examples. 'Nei Mama - O-Kana Mama', 'Dhoa tulsi' are but a few examples.

The same proverbs are related to folk belief which may be a superstition in varying degree. Sunil Gangopadhyay has written a poem based on folk superstition without any specified reference to the proverb concerned: 
Just at noon ten past three there is a shrill whistle beneath the broken ghat.

Has anybody heard?

Old proverb says, it is better not to hear. (Gangopadhyay 1998: 163)

According to the old saying, it is better not to listen to an inauspicious sound that continues for long. But the poet uses the proverb in the same other sense that there are some queer incidents in human life which must be left unattended. Man waits for someone who never comes; he uncovers a queer truth in the name of going to see the river or he happens to leave letter ever unfinished. It is equally useless to try for a meaning of a queer incident and hence the proverbial wisdom that warns not to hear something unwanted. Here the poet develops the idea in the style of 'bakyannoi lokaabharan' with the help of a proverb pertaining to folk superstition.

Amrita Pritam, one of the noted female poets in India, refers to coconut as a magical fruit for a woman who would be a mother very soon. Out of the nine dreams that she dreamt before the annunciation the poet describes the seventh one, Magical Fruit, in the following manner:

I cracked the coconut.

People come to partake of its kernel

I poured the jujus of the unripe fruit

Into a vessel.

No ritual, no superstition.

People took their share, it still remained.

What was this coconut? What was this dream?

How long stretch the threads of dreams?

I touched my breasts and the jujus of the coconut

Oozed out. (Sing 1982: 153)

This is how the seventh dream of Tripta, a pregnant woman with all her cravings of unripe pregnancy and restless heart, is described. The whole incident appears to be a queer one as she could not know where from the coconut came in her lap. There is a proverb that coconut contains juice inside only as a device of God. The woman having concern for neither a ritual nor any superstition could not know the meaning of the coconut; nor could she know the queer incident of the juice of coconut oozing out of her breasts. Thus the proverbial saying about a coconut is artistically expressed in the style of 'lokaabharan'.

There is an Indian proverb concerning the occult nature of religion which goes as follows:

Dharmasya tattwam nihitam guhayam. 
This proverb, like many others in Sanskrit, is taken for granted as a proverbial saying. This proverb is again used in a different poetic language artistically in a poem by Amrita Pritam.

The poem with the title Rule of Religion reads as follows:

Burden

Of innumerable questions

On the shoulders of men

But religion is kind

It buys every question

If one can wait for the answer

(Till eternity). (Sing 1982: 133)

If one cannot realize the meaning of religious theories, one may ask neverending questions which, in turn, are never answered. Here the underlying element of this poem happens to be a folk element based on a proverbial saying. The style of 'bakayannoi lokaabharan' is very much evident here.

The Indian concept of time ('kala', Sanskrit for 'time') is very much expressed by the concept of four Ages - namely, Satya, Treta, Dwapara and Kali. Kali Yuga (the Age of Kali), as a result, has become a popular folk concept leading to a proverbial as well as an idiomatic expression. There are various other proverbial sayings regarding Kali Yuga such as:

Abaak kali paape bharaa (Oh Kali! Full of sins!)

Abaak kali! Baak sare naa (What Kali is! One becomes dumbfounded.)

All such proverbial exclamations stem from a basic notion that the age of Kali (since 3101 BC) will continue until the revival of Satya Yuga or the Age of Righteousness, followed by three other ages. Proverbial Kali Yuga is irreligious, corrupt, unrighteous and full of injustice. So exclamations relating to Kali Yuga have often been transformed into poetic creations in the style of 'lokaabharan'.

Rambilas Sharma, a modern Hindi poet, for instance, composed a poem with the title Kali Yuga in the style of 'lokaabharan':

Yuga yuga nindita yah kali-yuga,

yahi hay hamara yuga;

chetana ki kirane simpat kar ek sath

schinnakarne ke jar jal-star, sacroiya samcita hay

nasta karne karne ko satyuga hi ke puratan krimi-kit. (Sharma 2000:210)

Satya Yuga, in the recurrent cycle of time is one uncorrupted and immemorially ancient and Kalikaal as a folk conception is the last and the worst of all the 
four ages. At the end of which the world is supposed to be destroyed. But the poet being hopeful of the prospect of Kalikaal rebuilds the idea like this:

Visaal sakiyata,

Yahi hay hamare yuga,

Visakta jaldhi ke hriday me,

Fut kar dhire dhire ut raha kamal yaha,

Khilega jo ek din kale jaltal par

Naba arunabha-me-naa, Satya Yuga ke prakad me

Here the poet tries to go beyond the proverbial saying and reiterates his hope for yet another Satya Yuga within the cycle of Kali Yuga.

A number of Indian proverbs are based on Indian mythology and mythological concepts that are intrinsically allied to folk mind. It may be related either to a concept like 'Swati Tara', a star in the sky, or some character or incident that is available in Indian Puranic tales or the like. Many modern poets use such Indian proverbs as are related to Indian Puranic myths.

'Ravaner Siri' (or 'Swarger Siri') and 'Ravaner Chita', for example, are but two remaining untypical examples. It is believed that Ravana, the king of Lanka, tried to build up a staircase leading to the Heaven, the abode of god, and he left it unfinished. Again, the concept of 'Ravaner Chita', to Indian folk mind, relates to a funeral pyre that is never extinguished. According to the popular story, it all happened as per a boon of Ramachandra who gave it to the widow of Ravana as a consolation.

Premendra Mitra, a modern Bengali poet, used these proverbs in his poem Dasanan being another popular name of Ravana. He used the proverb 'Swarger Siri' by a method of splitting it into two distinct units of sentences thereby using the style of 'bakyannoi lokaabharan'. The poet used two short sentences representing two words contained in the proverb as shown below:

Units of the proverb / Expanded use in the poem / English translation

1 Swarga(Heaven) Swarga aajo dur Heaven is far away.

2 Siri (staircase) Sopan Haini Gara The staircase is yet to be completed.

It is evident that what remains suggestive in proverbial units has been expressed in poetic terms. So the poet writes. In the method of splitting the units of the proverb into two sentences. 
The staircase is yet to be built up.

Heaven is a faraway place to reach.

Now the poet in his poetic address to Ravana the Puranic 'King of Lanka' employees 'bhabanny lokaabharan' by way of conjoining the idea of the proverb 'Swarga Siri', used earlier, with a new one - 'Ravaner Chita' (the funeral pyre of Ravana) in the following lines:

That is why I understand

Your funeral pyre, according to proverbial sayings,

Is never extinguished,

$O$, lover of the earth,

Ever revolutionary (Mitra 1977: 202).

The poet here clearly refers to the proverbial saying of the funeral pyre of Ravana with an added note of explication. The pyre of Ravana is never extinguished not because of Rama's blessings to Ravana's widow, but because it stands as a symbol of an "ever revolutionary" who wanted to bring the rightness to Heaven for all human beings.

It is believed that Ramachandra blessed Mandodari, widow of Ravana, for that she did not wipe out her sindur (vermilion) on the forehead, the sign of marital status for a woman, as soon as funeral pyre would blow out. The proverb has been used in this poetry with a new implication instead of the old Puranic tale.

As regards Indian proverbs relating of a celestial body as a star in the sky, there is a proverb in Bengali which goes as follows:

Swati nakshatra'er jol

Patra bujhe phal

[The water falls from the star swati

The result depends upon what it falls.]

It is a proverbial expression rooted in a folk belief that pearl oysters are born in those shells that drink drops of rain water falling from the sky while the star 'swati' shines. Time and again, Indian poets have used this proverbial in order to recreate it in the style of 'lokaabharan'. Sunil Gangopadhyay in one of his poems writes:

Yamuna. I keep you as a neighbor to a star

Are you not really a celestial drop of water

Soaked with the proverbial star, Swati?

(Gangopadhyay 1995: 158) 
This being a love poem is symptomatic of an intense feeling of a lover who creates poetic lines out of his deep love for the one he adores, so the proverbial story gains yet another dimension as Yamuna, as good as Swati, inspires him to create new poems, as nice as pearls.

It is contextualization of proverbs or proverbial utterances in relation to the style of 'lokaabharan'. There are uses of words similar or dissimilar either in the meaning or context. It all depends on how skilful a poet is in using various proverbial verbs or sentences in a method of composite transfer.

Various folk elements are used in the process of poetic creation according to the tone feeling. Proverbial names together with proverbial senses play a pivotal part in the process of creation, as a result of which the style of 'lokaabharan' happens to be a characteristic mode of expression. In other words, proverbial word elements are actually fitted into the text with the flair and flamboyance of the style of 'lokaabharan'.

\section{COMMENTS}

${ }^{1}$ Bikshipta Chinta, Swarganagarer Chibi. Transl. by Biplab Chakraborty.

\section{REFERENCES}

Bharati, Dharamvir 1999. Kovita Ki Mout, Dharanbin Bihar. Dusra Saptak. Ajneya (ed.). Seventh ed. New Delhi, p. 175.

Chakraborty, Biplab 2005. Lokaabharan: A Style in Modern Bengali Poetry. Journal of the Asiatic Society, vol. XLVII, No. 2.

Gangopadhyay, S. 1998. Bakul, Bakul, Katha bolo, Nora Harie Jeona. Kabita Sangraha. Vol. 3, p. 163.

Gangopadhyay, S. 1995. Prabaser sise. Kabita Sangraha, Vol. 1. Kolkata, p.158.

Gaur, Ramesh 1975. Selected Poems of Umashankar Joshi, The Moment of Death. Pratinidhi Kavitayen. [A Collection of Representative Poems] Transl. by Dalpat Padhiyar. Gujarat Sahitya Academy, 1998. pp. 685-686.

Ghosh, Shankha 1980. Agasthya Yatra. Kabita Sangraha, Vol. I, 1401 BS, p.81.

Mitra, Premendra 1997. Dajanan, Chay Dasakel Kovita. p. 202 - Transl. by Biplab Chakraborty

Nagarjun, Rajkamal 1998. Dhyanmagna vakasiromani 1988. Pratinidhi Kavitayen [A Collection of Representative Poems]. 3rd ed. New Delhi, p. 57.

Nazrul Islam, Kazi 1996. Pother Disha. Rahnavali, Vol. 1. Dhaka, p. 332.

Ranchanavali, Rabindra 1980. Bhakti-O-Otibhakti, Kanika, Vol. 1, Govt. of West Bengal, p. 705.

Roy, Annada Shankar 1998. Dhauta Tulsi Patra Chara Samagra. Kolkata, p. 323. Transl. by Biplab Chakraborty. 
Sharma, Rambilas 2000. Taar Saptak [Hindi Poems], Ajneya (vol. ed.), Seventh ed., New Delhi, p. 210.

Sing, Khushwant (ed.). 1982. Nine Dreams and the Annunciation. Selected Poems of Amrita Pritam. New Delhi 1982, p. 153. 